\title{
Analysis of budget spending and its affect on Jambi Government performance
}

\author{
Heriberta; Aulia Tasman; Yanilia
}

\author{
Master Program in Economics, Graduate Program of Jambi University, Indonesia \\ e-mail correspondence: eheriberta@yahoo.com
}

\begin{abstract}
The purpose of this research are: 1) to investigated the tendency of budget absorption to regional working units (SKPD in Indonesian) expenditure in the provincial government of Jambi; 2) to analyze factors that influence the SKPD's budget absorption in the provincial government of Jambi; 3) to examine the effect of budget absorption on agency performance in the provincial government of Jambi. The data used in the research are secondary data in the form of budget realization reports, and primary data by using questionnaires. The population in this research are all SKPD in the environment of the provincial government of Jambi. The data analysis tools used in this research is Partial Least Square (PLS). The research finding shows that 1) all SKPD in the environment of the provincial government of Jambi tend to be delayed in budget absorption. About $82.61 \%$ SKPD tend to be delayed in budget absorption of personnel expenditure. All SKPD tend to be delayed in budget absorption of goods and services expenditure, and $43.90 \%$ SKPD tend to be delayed in budget absorption of capital expenditure; 2) budget planning and budget execution are the factors that affect the budget absorption significantly, while capacity of human resources has no effect on the budget absorption, and 3 ) the budget absorption has a positive and significant impact on the agency performance in the provincial government of Jambi.
\end{abstract}

Keywords: Capacity of human resources, Budget planning, Budget execution, Budget absorption, Agency performance

\section{INTRODUCTION}

Regional budget is one of the tools that play an important role in order to improve public services and in it reflected the needs of the community with pay attention to the potential and sources of local wealth. A good budget will reflect into effectiveness of government performance in the public, then the government should be enable to create a mature and realistic budget to be realized so that the welfare of the community can achieved. Public sector budgeting is an instrument of accountability for the management of public funds and the implementation of programs financed from public money (Mardiasmo, 2009) .

The local government has a role to optimize the management of local budgets in order to benefit the welfare of society as it has been mandated into the Government Regulation No. 58 of 2005. However, look at the implementation still many things expected by public on the government for improved welfare that it is not be fulfilled yet. The realization of Regional Government Budget or APBD in Indonesian (direct expenditure) capital expenditure budget in Year A of 2015 budget all districts/municipalities in Indonesia is estimated to be 15 percent so that the amount of expenditure that can be utilized for public interest is not yet optimal in achievement. 
The problem of less than optimal absorption of the budget occurs because the absorption is always low at the beginning of the year and will eventually accumulate at the end of the year. In fact, local regulations on APBD have been approved since the end of December of the previous year so that programs and activities should be implemented early in the year (Aini, 2016).

Absorption the budget can be seen from two points of view. The first view, budget absorption in question is the realization of the budget at the end of the year compared with budget. The second view, the absorption of the budget meaning is the disproportionate absorption of the budget marked slowly at the beginning of the year and accumulate at the end of the year (Halim, 2016 ).

Delays of budget absorption to be one of the classic problems that continue to occur each year in Indonesia. Indonesia as a developing country by the World Bank is included as one of the countries with slow budget absorption and back loaded expenditures. Budget absorption at the beginning of the year (first quarter) is so small but has increased significantly at the end of the year (fourth quarter). This has an impact on the slow realization of program implementation and government activities (Malahayati, et.al, 2015). This phenomenon also happened to Jambi Provincial Government.

Base on the data of budget absorption of Jambi provincial government in 20142015, the first quarter showed a very low budget absorption even when passing through the second quarter, expenditure still low only able to be absorbed less than 50 percent. That is, many program / activity completion will accumulate at the end of fiscal year. Many regional working units (SKPD in Indonesian) are overly cautious when doing so seems slow budget spending and optimal use of the time. The fifteen-month budget year of the sea will be effective only for 5-6 months. Many SKPD are just beginning to work in the second quarter. This causes the implementation of programs/activities to be ineffective and efficient.

The amount of Jambi Province government spending keep increasing from year to year. The increase in portion of expenditure is not matched by maximum budget absorption. The average absorption rate of Jambi Province direct spending in the period of 2011-2015 amounted to 89.89 percent, or in other words there is still an unabsorbed percentage of budget of 10.03 percent. Absorption of the budget that is not optimal seems to make the budget area so great looks in vain. Low absorption of the budget poses macroeconomic risks and does not achieve economic growth targets. Meanwhile, slowing budget absorption or accumulation in the last quarter will also create local financial accountability risks, such as imposing unnecessary activities, weak planning of activities, and decreasing quality of implementation of activities (Halim, 2016).

Absorption of a late and low budget needs to get serious attention from the government. Based on previous studies, the factors that allegedly affected the absorption of the budget include human resource factors, budget planning factors, and budget implementation factors.

The first factor, human resources in this case civil servants as the financial management apparatus also become one of the factors that affect the absorption of the budget. This is in accordance with the research finding of Maulana (2011) which states that not yet maximize the absorption of budget usage of APBD by some SKPD indicates that SKPD has not been able to maximize human resources.

The second factor affecting budget absorption is budget planning. The problems that arise in budget planning are due to the assumption that not all proposed budgets will be approved so that the proposed budget is greater than required without 
considering the ease of implementation and real needs in the field (Septianova and Helmy, 2013).

Yunarto (2011) stated that poor budget planning often creates obstacles in the implementation, so it should be revised or even cannot be realized at all. This thing is in accordance with the statement Muchsin and Noor (2011) that the cause of the low absorption caused in the budget planning stage is usually because it is still waiting for the approval of APBD, which is late received by SKPD.

The third factor, budget absorption according to Malahayati, et.al, (2015) is also affected by budget execution. The problems that often occur within the internal work unit include the delay in determining the decision of the finance manager, the habits of the budget manager to delay the work, and the absence of rewards and punishment for the success or failure of financial management in the work unit also leads to the slow absorption of the budget (Miliasih, 2012) .

The payment mechanism of money supply by Herriyanto (2012) becomes a problem that occurs in the execution of the budget due to the withdrawal application is not optimized only once a month withdrawal and the need for office funds that require substantial funds but cannot be accounted - account for the disbursement documents so that slow down the process of applying for inventory money. Furthermore, Siswanto and Rahayu (2010) stated that related to the procurement process of goods / services, the prudence of procurement officers in taking action, lack of certified procurement committee, and poor implementation of procurement of goods / services in SKPD also contributed to the slow absorption budget.

Budget absorption in performance-based budgeting frameworks is not the target of budget allocation. However, up to now, one of the indicators used to assess the performance of local governments is the absorption of the budget. Budget absorption reflects the ability of local governments to implement and account for any planned activities (Mardiasmo, 2009). The same thing is expressed by Haspiarti (2012) that the use of budget must be accountable by using the result of the expenditure of public funds so that in the end can be obtained picture about performance of government institution.

The performance of government agencies has been in the spotlight in recent years, especially since the emergence of a more democratic climate in government. Some of people questioned of the value they receive for services carried out by local governments. Although the routine and development budgets issued by the government are increasing, it seems that people are not satisfied with the quality of services or goods provided by the local government (Stepanus, 2014).

Based on research of Sukadi (2012), Zarinah (2015), Ruwaida, et.al (2015) and Malahayati (2015) proved that human resource factors, budget planning and budget execution have an impact on SKPD budget absorption. According Fitriany et al (2015) proves that simultaneously the budget-planning factor, budget execution, internal unit, HR, document, and administration affect the accumulation of budget absorption at the end of the year, but only the human resource factor and the influencing document factors against the accumulation of budget absorption at the end of the year. Furthermore, Rifai, et al (2016) states that planning, regulation, coordination, implementation, decentralization and human resources have no effect on the delay of budget absorption in SKPD NTB Provincial Government.

This research is an extension of Herriyanto (2012), Miliasih (2012), and Kuswoyo (2012) research where the study looks at the problem of delay and low budget absorption. The difference between this study and previous research is previous research using exploratory factor analysis method (Exploratory Factor Analysis) to analyze the 
factors causing the delay of budget absorption. Past research has yet to test the effect of the above factors - factors that affect the delay on budget absorption.

Some of the factors that have been identified in previous research will serve as the independent variables that affect the absorption of an expenditure that is the capacity of human resources, budget planning and budget execution as in research Zarinah (2015), Malahayati (2015) and Rifai et.al (2016). However, this study will also look at the effect of budget absorption on agency performance.

The budget cycle consists of budget planning / budgeting, budget execution, budget monitoring, and budget reporting and accountability. Budget realization becomes an important thing for government agencies because it becomes one of the SKPD performance benchmarks. However, since 2011 until the year 2015 the phenomenon that occurred in Jambi Province showed less optimal budget absorption and tends to be escalated at the end of the year. The disproportionate disbursement of budgets affecting government programs and activities and/or public services cannot be accomplished quickly and well.

Delay in budget absorption and low budget absorption rate issues that are often discussed in the execution of government budgets. The government has attempted, but the regulatory issues continue to recur. The delay in the absorption of this budget will affect the implementation of programs and activities in the government agencies that is to affect the performance of agencies. Report on evaluation result of performance accountability of Jambi Provincial Government Institution conducted by Ministry of Administrative Reform and Bureaucratic Reform (KemenPAN and RB) shows the performance of Jambi Province institution Year 2015 is still CC category with value 52,87 .

Based on the explanation proposed then it can be formulated the problems in this study are: 1) How the tendency of uptake of government agencies (SKPD) budget in Jambi Provincial Government?; 2) What factors influencing of budget absorption of SKPD budget in the Provincial Government of Jambi?; 3) How is the influence of SKPD budget absorption on the performance of Jambi Provincial Government institution?

\section{RESEARCH METHODS}

The data in this study is secondary data in the form of budget realization report SKPD in Jambi Provincial Government and primary data by using questionnaire. The population in this research is all SKPD in Jambi Provincial Government. The number of respondents in this research is 71 respondents by using purposive sampling method with the apparatus criteria, which is located as the head of planning and financial subdivision of SKPD, and has the main duty and function as PPK (Commitment Making Official) and PPTK (Officials technical implementation activities).

Data analysis method used is descriptive analysis method to look at the trend of budget absorption SKPD and SEM-PLS to look at the factors that influence the uptake of the budget and budget absorption influence on the performance of government agencies. The structural equation model in this research is:

$$
\begin{aligned}
& \eta_{1}=\gamma_{1} \xi_{1}+\gamma_{2} \xi_{2}+\gamma_{3} \xi_{3}+\varsigma_{1} \\
& \eta_{2}=\beta_{1} \eta_{1}+\varsigma_{2}
\end{aligned}
$$

Remark:

$\xi=$ exogenous latent variable 
$\eta=$ endogenous latent variable

$\beta=$ coefficient of influence of endogenous variable to endogenous variable

$\gamma=$ coefficient of influence of exogenous to the variable to endogenous variable

$\varsigma=$ Zeta, model error

\section{RESULT AND DISCUSSION}

\section{Analysis of budget absorption of SKPD of Jambi Provincial Government}

The evaluation result on the budget realization report of SKPD within Jambi Provincial Government Fiscal Year 2015 can show the level of SKPD budget absorption as shown in table 1.

Table 1. Absorption level of government budget for Jambi in FY 2015

\begin{tabular}{lrrrr}
\hline \multirow{2}{*}{ Quarter } & \multicolumn{2}{c}{$\begin{array}{c}\text { Cumulative Budget } \\
\text { Absorption }\end{array}$} & \multicolumn{2}{c}{$\begin{array}{c}\text { Absorption budget } \\
\text { per Quarter }\end{array}$} \\
\cline { 2 - 5 } & \multicolumn{1}{c}{ Rp } & \% & Rp & \% \\
\hline I (January-March) & $135,681,541,959$ & 7.79 & $135,681,541,959$ & 7.79 \\
II (April-June) & $515,550,159,798$ & 29.60 & $379,868,617,839$ & 21.81 \\
III (July-September) & $918,013,307,121$ & 52.71 & $402,463,147,323$ & 23.11 \\
IV (October-December) & $1,663,360,224,945$ & 91.13 & $745,346,917,824$ & 40.83 \\
\hline
\end{tabular}

Source: Data of LRA SKPD 2015 processed, 2017

Table 1 shows that the average absorption of Jambi Provincial Government budget for Fiscal Year 2015 cumulatively tends to increase from quarter to quarter. The absorption of the budget per quarter was seen to increase each quarter, but the absorption of expenditure in the first quarter tended to be low. If viewed proportionally the budget absorption rate per quarter is not proportional. Absorption of the quarterly budget is below the 25 percent proportional level for the first, second and third quarters. Cumulatively, the budget absorption rate until the end of the first quarter was still 7.79 percent.

Low budget absorption at the beginning of the year will trigger high absorption by the end of the fiscal year. Table 1 shows that the largest budget absorption occurred in the fourth quarter of 40.83 percent. This indicates that the accumulation of budget realization in the fourth quarter.

The analysis of SKPD budget absorption in Jambi Provincial Government tends to be delayed, and the level of delay in budget realization is shown in Table 2 .

Table 2. The level of delay in fiscal secondary spending in Quarter III in FY 2015

\begin{tabular}{ccc}
\hline Delay Rate & Amount of SKPD & \% of Total SKPD \\
\hline High & 1 & 2.17 \\
Medium & 14 & 30.43 \\
Low & 31 & 67.39 \\
amount & 46 & 100 \\
\hline
\end{tabular}

Source: Data of LRA SKPD 2015 processed, 2017

The result of analysis of the tendency of budget absorption shows that cumulatively the tendency of low budget absorption rate in the first and second quarter. This triggered a high level of realization at the end of the budget year, indicated by the uneven rate of absorption in each quarter. Absorption of uneven expenditure budget is caused only by employee expenditure, which tends to be more consistent absorption in every quarter. While absorption in addition to personnel spending uneven trend in every quarter. Budget realization per type of expenditure is cumulative compared with budget realization per type of quarterly spending shown in Table 3. 
Table 3. Absorption of Jambi Province expenditure budget by type of expenditure FY 2015

\begin{tabular}{lcccccc}
\hline & \multicolumn{2}{c}{ Cumulative Shopping Spend (\%) } & \multicolumn{3}{c}{ Spending Absorption per Quarter (\%) } \\
\cline { 2 - 7 } Quarter & $\begin{array}{c}\text { Employee } \\
\text { Expenditure }\end{array}$ & $\begin{array}{c}\text { Shopping } \\
\text { Goods \& } \\
\text { Services }\end{array}$ & $\begin{array}{c}\text { Capital } \\
\text { Expenditure }\end{array}$ & $\begin{array}{c}\text { Employee } \\
\text { Expenditure }\end{array}$ & $\begin{array}{c}\text { Shopping } \\
\text { Goods \& } \\
\text { Services }\end{array}$ & $\begin{array}{c}\text { Capital } \\
\text { Expenditure }\end{array}$ \\
\hline Q I & 22.47 & 4.86 & 8.83 & 22.47 & 4.86 & 8.83 \\
Q II & 43.43 & 27.61 & 29.78 & 20.96 & 22.75 & 20.95 \\
Q III & 65,33 & 48.90 & 54.96 & 21.90 & 21.29 & 25.18 \\
Q IV & 81.86 & 88,50 & 95,36 & 28.81 & 41.07 & 42.55 \\
\hline
\end{tabular}

Source: Data of LRA SKPD 2015 processed, 2017

Table 3 shows that the accumulative spending of expenditures across quarterly for each type of expenditure except for personnel expenditure experienced a low trend at the beginning of the year and increased sharply in the fourth quarter. While the level of expenditure realization per quarter for each type of expenditure except personnel expenditure experienced the greatest tendency in the fourth quarter.

\section{Analysis of trend of employee expenditure budget absorption}

The analysis result of the delay level of realization of Jambi Provincial Government personnel as a whole shows that budget absorption rate is above $68 \%$ at the end of September. However, when viewed per SKPD then the results of late analysis in quarter III will be seen in Table 4.

Table 4. Level of late employee expenditure realization Quarter III FY 2015

\begin{tabular}{ccc}
\hline Delay Rate & Amount of SKPD & \% of Total SKPD \\
\hline High & 2 & 4.35 \\
Medium & 14 & 30.43 \\
Low & 22 & 47.83 \\
\hline Total & $\mathbf{3 8}$ & $\mathbf{8 2 . 6 1}$
\end{tabular}

Source: Data of LRA SKPD 2015 processed, 2017

Table 4 shows that $82.61 \%$ SKPD tend to experience delays in absorption of personnel budget, but tendency of delay in absorption into low category. That is, there are $17.39 \%$ SKPD which is not categorized as late in budget absorption due to the absorption of personnel budget up to the end of III quarter above $68 \%$.

\section{Analysis of trend of budget absorption of goods and services}

The budget for goods and services expenditure in 2015 is owned by all SKPD in Jambi Provincial Government that is 46 SKPD. It can be seen from Table 3 that the realization of cumulative goods and services expenditure tends to be low at the beginning of the year up to the end of the third quarter. The absorption rate of the budget until September only reached $48.90 \%$, where the total absorption rate is 88.50 $\%$ of the budget so that $41.07 \%$ of the absorption of goods and services expenditures occurs in the fourth quarter.

Table 5. Level of delays realization of goods and services expenditures Quarter III FY 2015

\begin{tabular}{ccc}
\hline Delay Rate & Amount of SKPD & \% of Total SKPD \\
\hline High & 1 & 2.17 \\
Medium & 17 & 36.96 \\
Low & 28 & 60.87 \\
\hline Amount & 46 & 100,00 \\
\hline
\end{tabular}

Source: Data of LRA SKPD 2015 processed, 2017 
The level of delay in the realization of the expenditure budget for goods and services in the third quarter of FY 2015 is shown in Table 5. Table 5 shows that at the end of the third quarter of 46 SKPD (100\%) in Jambi Provincial Government, the manager of goods and services expenditure experienced a delay in the absorption of budget for goods and services. At the end of Q3 / 2015, there was no SKPD with realization of goods and services expenditure above $68 \%$.

\section{Analysis of trend of budget absorption of capital expenditures}

In Fiscal Year 2015 there are 41 out of 46 SKPD within Jambi Provincial Government that manage capital expenditure. SKPD that does not manage this capital expenditure is under the Regional Secretariat of the Law Bureau, Government Bureau, Development and Cooperation Administration Bureau, Bureau of Economic and Natural Resources Administration, and Bureau of Public Welfare and Community.

Table 2 shows that cumulative capital expenditures tend to be low at the beginning of the year to the end of the third quarter. The absorption rate of the budget until September was only $54.96 \%$, where the total absorption rate was $95.36 \%$ of the budget change so that $42.55 \%$ of capital expenditure absorption occurred in the fourth quarter. The level of delay in capital expenditure realization in the third quarter of FY 2015 is shown in Table 6.

Table 6. Late expectation rate of capital expenditures Quarter III FY 2015

\begin{tabular}{ccc}
\hline Delay Rate & Amount of SKPD & \% of Total SKPD \\
\hline High & 2 & 4.88 \\
Medium & 7 & 17.07 \\
Low & 9 & 21.95 \\
\hline Amount & $\mathbf{1 8}$ & $\mathbf{4 3 . 9 0}$ \\
\hline
\end{tabular}

Source: Data of LRA SKPD 2015 processed, 2017

Table 6 shows that 18 out of 41 SKPD (43.90\%) managing capital expenditures tend to experience delays in budget absorption. That is, 23 SKPD (56.10\%) that is not included in the category of late because the absorption rate of its budget is above $68 \%$ at the end of the third quarter. This indicates that the absorption of capital expenditure budget in FY 2015 has started to be orderly, where more than $50 \%$ of SKPD that manage capital expenditure do not experience any delay.

Analysis of factors affecting budget absorption and its influence on the performance of Jambi provincial government agencies

The number of questionnaires distributed in this study were 71 questionnaires, with $100 \%$ return rate so that all questionnaires are suitable for further analysis. The analyzes include descriptive statistical analysis and inferential analysis.

Table 7. Descriptive statistics by variables

\begin{tabular}{lcccccc}
\hline \multicolumn{1}{c}{ Variables } & N & $\begin{array}{c}\text { Theoretical } \\
\text { Range }\end{array}$ & $\begin{array}{c}\text { Theoretical } \\
\text { Meaning }\end{array}$ & $\begin{array}{c}\text { Actual } \\
\text { Range }\end{array}$ & $\begin{array}{c}\text { The } \\
\text { Actual } \\
\text { Mean }\end{array}$ & $\begin{array}{c}\text { Standard } \\
\text { Deviation }\end{array}$ \\
\hline Human Resource Capacity & 71 & $4-20$ & 12 & $5-19$ & 10.761 & 2,836 \\
Budget Planning & 71 & $5-25$ & 15 & $9-24$ & 15.718 & 4,061 \\
Budget Implementation & 71 & $3-15$ & 9 & $5-15$ & 9,620 & 2,167 \\
Budget Absorption & 71 & $6-30$ & 18 & $10-28$ & 17,197 & 4,569 \\
Agency Performance & 71 & $5-25$ & 15 & $5-25$ & 15.507 & 4,039 \\
\hline Source: Primery
\end{tabular}

Source: Primary data processed, 2017 
The results of descriptive statistical analysis are shown in Table 7. $\mathrm{R}$ averages of respondents stated that human resource capacity is still low, budget planning is good enough, budget execution is quite good, budget absorption is still low, and agency performance is quite good.

Inferential Analysis (Goodness of Fit) using SEM PLS done through 2 stages of evaluation of outer model and evaluation of inner model. Outer model evaluation consists of convergent validity test and discriminant validity test. The result of the convergent validity test shows that all indicators are valid as the value of outer loading ranges above 0.50 as shown in Figure 1.

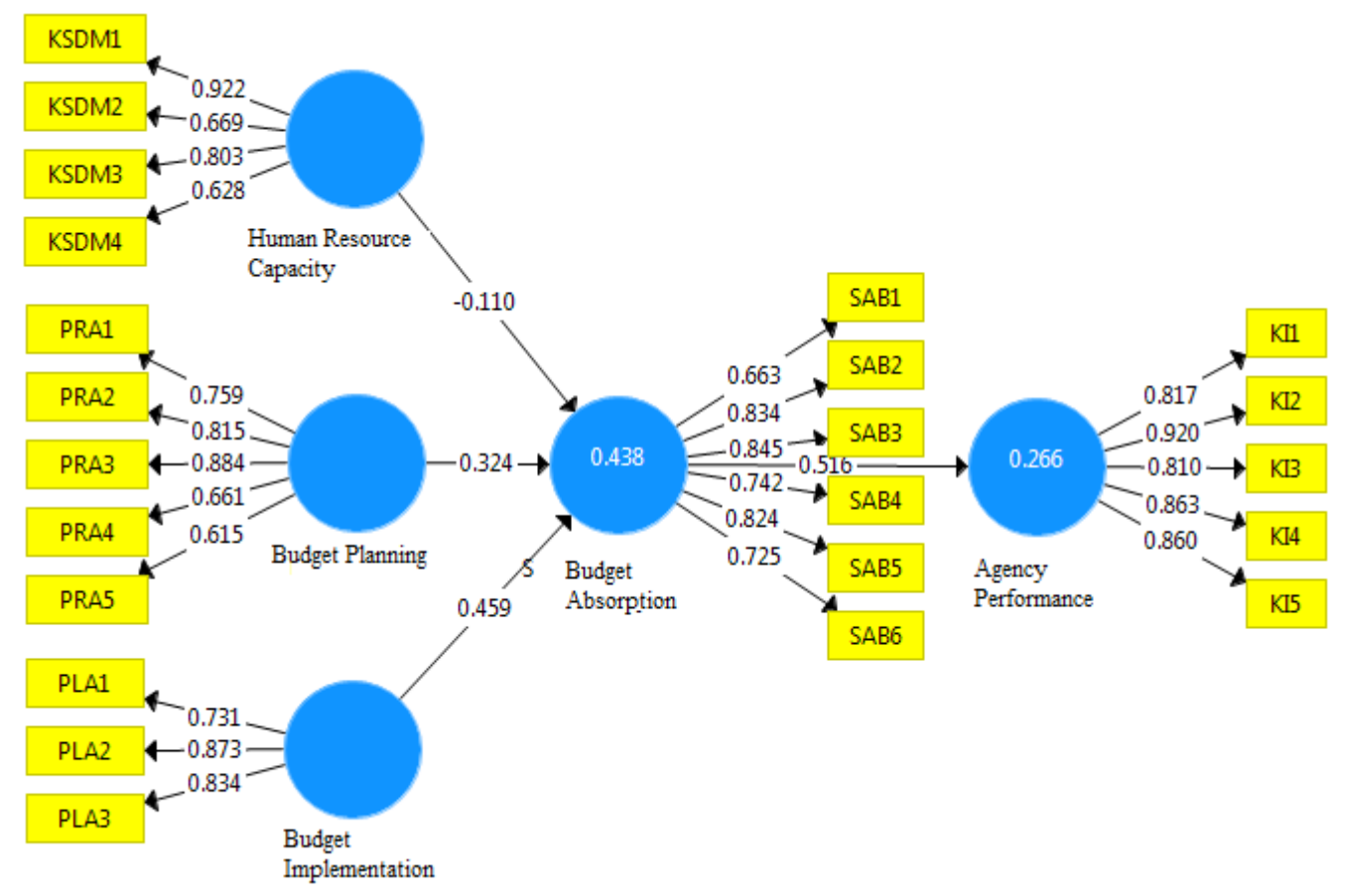

Figure 1. Output PLS algorithm

Discriminant validity test shows the correlation value of cross loading of all indicators of human resource capacity to latent variable is greater than cross correlation value of other latent variables because it ranges from 0.63 to 0.92 so that all HR capacity indicator is valid. The correlation value of cross-loading of all budget planning indicators to latent variables is greater than the cross correlation value of other latent variables because of the range 0.62 to 0.88 , so that all indicators of budget planning are valid. Likewise, the cross correlation value of loading all the indicators of implementation of the budget of the latent variable is greater than the value of the cross correlation for loading other latent variables ranged from 0.73 to 0.87 , so that all the indicators of implementation of the budget is declared invalid.

The correlation value of cross-loading of all expenditure absorption indicators to latent variables is greater than the cross correlation value of other latent variables because it ranges from 0.66 to 0.85 , so that all expenditure absorption indicators are valid. The correlation value of cross-loading of all agency performance indicators to latent variables is also greater than the cross correlation value of other latent variables because it ranges from 0.81 to 0.92 , so all the indicators are also valid.

Meanwhile, all latent variables are considered reliable because of the value of AVE $>0.50$; value of composite reliability and Cronbach Alpha value $>0.70$ as shown in Table 8. 
Table 8. Average Variance Extracted (AVE), Composite Reliability (pc) and Cronbach Alpha

\begin{tabular}{lcccl}
\hline \multicolumn{1}{c}{ Construct Variables } & AVE & $\begin{array}{c}\text { Composite } \\
\text { Reliability }\end{array}$ & $\begin{array}{c}\text { Cronbach } \\
\text { Alpha }\end{array}$ & Information \\
\hline Human Resource Capacity (KSDM) & 0,584 & 0,846 & 0,791 & Reliable \\
Budget Planning (PRA) & 0,567 & 0,866 & 0,804 & Reliable \\
Budget Implementation (PLA) & 0,664 & 0,855 & 0,744 & Reliable \\
Budget Absorption (SAB) & 0,601 & 0,900 & 0,865 & Reliable \\
Agency Performance (KI) & 0,731 & 0,931 & 0,907 & Reliable \\
\hline
\end{tabular}

Source: Primary data processed, 2017

Evaluation of structural model or inner model is done by bootstrapping test, which yields coefficient value of determination $\mathrm{R}$ square, $\mathrm{Q}$ square, path coefficients, and latent variable correlations. The coefficient $\mathrm{R}_{1}{ }^{2}$ of 0.438 indicates that the variation (change) that occurs in the variable of SKPD budget absorption at Jambi Provincial Government is $43.80 \%$ influenced by the changes that occur together on the variable of human resource capacity, budget planning and budget execution. The rest is equal to $56.20 \%$ influenced by factors of other variables not included in this research model. While the coefficient $\mathrm{R}_{2}{ }^{2}$ of 0,266 showed variations (changes) that occur in the variable performance of Jambi Province Government agencies of $26.60 \%$ influenced by changes in variable uptake of the budget, while the remaining $73.40 \%$ influence by factors of other variables not included in this research model

Q square predictive relevance for inner model is used to find out how well the observation value is generated by the model and the parameter estimation. The value of $\mathrm{Q}$ square $>0$ indicates the model has predictive relevance, otherwise if the value of $\mathrm{Q}$ square $\leq 0$ indicates the model lacks predictive relevant $\mathrm{e}$.

The result of calculation $\mathrm{Q}^{2}$ shows the value of 0.587 or $58.70 \%$. This means the model in this study is feasible or has predictive relevance to evoke endogenous variables of budget absorption and agency performance.

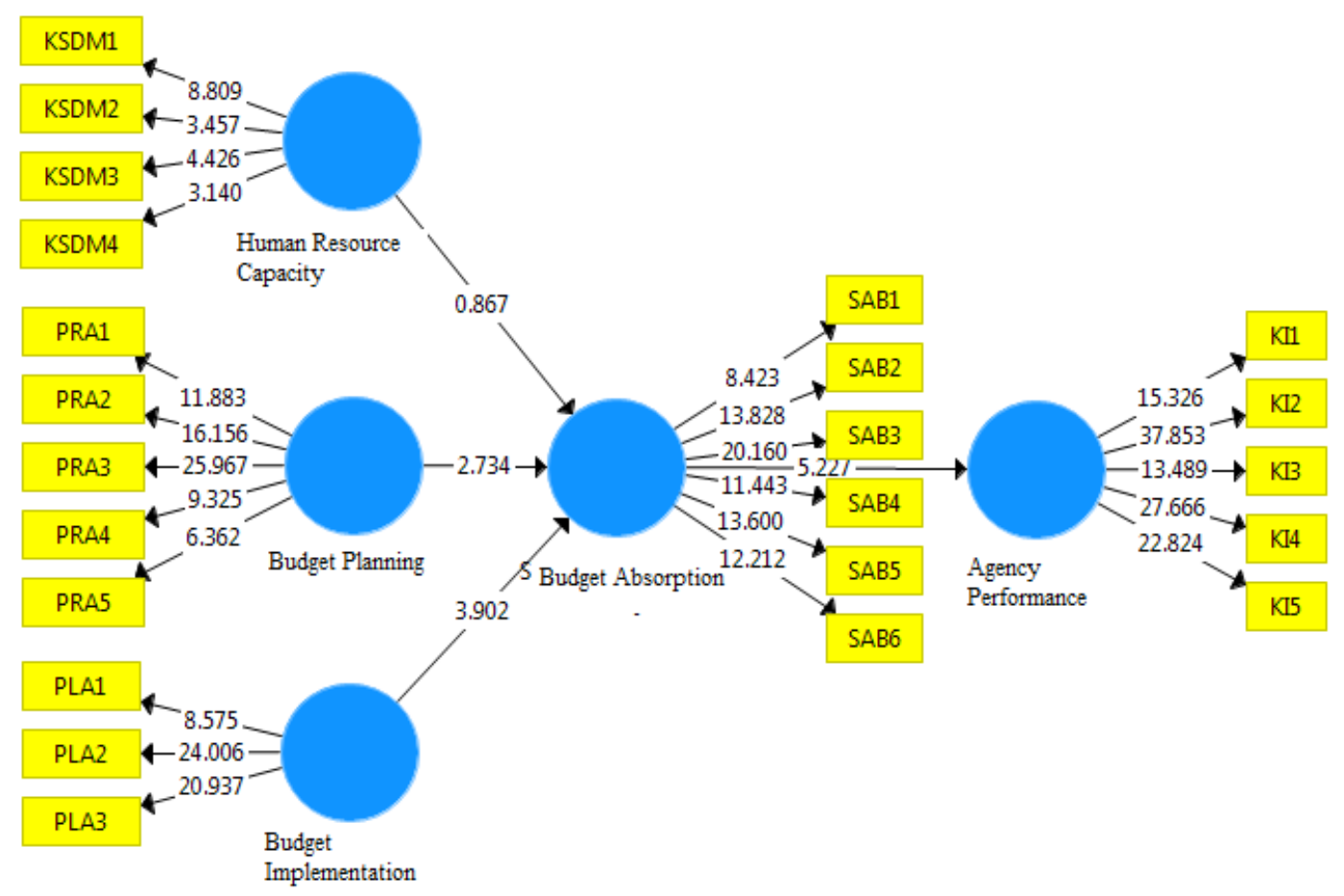

Figure 2. Bootstrapping output 


\section{Influence of human resource capacity on budget absorption}

The result of hypothesis testing showed that human resource capacity had negative and insignificant effect on the absorption of Jambi Provincial Government's budget with regression coefficient of -0.110 and $\mathrm{t}-$ statistic equal to 0.867 . The t- statistic value 0 , 867 is smaller than the t-table is 1.96 at the level of significance of alpha $5 \%$ then $\mathrm{H}_{\text {a }}$ rejected. That is, the increase or decrease in human resource capacity does not affect the absorption of the budget.

\section{Influence of budget planning toward budget absorption}

The results showed that budget planning has a positive and significant effect on budget absorption by looking at the coefficient of regression of budget planning of 0.459 and t- statistic value of 3, 902. The t- stat value of this budget planning variables is greater than t-table that is 1.96 at the level of 5\% alpha significance. Based on hypothesis formulation hence alternative hypothesis $\left(\mathrm{H}_{\mathrm{a}}\right)$ accepted so that planning is a factor influencing budgetary uptake. This means that it is better for budget planning in budget / financial management to be more appropriate and high uptake of SKPD budget to Jambi Provincial Government.

\section{Effect of budget implementation on budget absorption expenditures}

The results showed that the budget implementation has a positive and significant effect on budget absorption by looking at the regression coefficient of budget implementation of 0.324 and the t- statistic value of 2,734 . The t- statistic value of this budget execution variable is greater than t-table that is 1.96 at the level of $5 \%$ alpha significance. Based on the hypothesis formulation, the alternative hypothesis $\left(\mathrm{H}_{\mathrm{a}}\right)$ is accepted so that budget execution is a factor affecting budget absorption. The better the budget execution in budget management/finance the more precise and high the budget allocation of SKPD to the Government of Jambi Province.

\section{The Influence of budget absorption on institution performance}

The result of hypothesis testing shows that the absorption of expenditure budget has positive and significant effect to the performance of the institution by looking at the regression coefficient of 0,516 and the t-statistic value is 5,227 . The t- statistic value of this budget absorption variable is greater than t-table that is 1.96 at the level of significance of alpha $5 \%$ then the alternative hypothesis $\left(\mathrm{H}_{\mathrm{a}}\right)$ is accepted. This means that the more precise and higher absorption of budget expenditures in budget management/finance, the better agency performance at Jambi Provincial Government.

\section{Policy implication of research finding}

The results of this study can be an input for the local government about the absorption of the budget, especially the Government of Jambi Province. The problem of budget absorption becomes a continuous problem because every year budget absorption, especially the procurement of goods / services tends to experience delays. The results of this study indicate that budget planning and budget execution is a factor affecting budget absorption. This indicates that local governments should continue to make improvements in budget planning and budget execution for the acceleration of budget absorption in order to improve the performance of agencies can be achieved. This can be done by means of each SKPD should make the following policies:

1. Using cost standard analysis (CSA) in the preparation of budget so that budget can be allocated according to requirement because at present most of SKPD in Province government have not yet applied it. 
2. Identify the types of expenditures procured through the tender process, direct appointments, or self-management.

3. Develop a plan of budget absorption accompanied by a procurement plan that is plan) is a systematic, planned budget spending was made for one fiscal year and are detailed for each month per type of expenditure as a tool to monitor the implementation of the achievement of performance working units (establishments).

4. Establish monthly/quarterly target of output and outcome (performance).

Some of these policies are expected to overcome the problems that occur in the absorption of the budget that has been happening so that the performance improvement of the Government of Jambi Province in particular can be achieved.

\section{CONCLUSIONS AND RECOMMENDATIONS}

\section{Conclusions}

The absorption of expenditure by total expenditures in $\mathrm{Q}^{3}$ showed that all SKPD tended to be delayed due to budget absorption below 68 percent. The absorption of personnel budget at the end of the third quarter indicates that 38 out of $46(82.61$ percent) of SKPD tend to experience delays. That is, 17.39 percent are not categorized as late in the absorption of the budget because the absorption of personnel budget up to the end of III quarter is above 68 percent.

The absorption of goods and services spending at the end of the third quarter indicates that all SKPD tend to be delayed because there is no budget absorption rate above 68 percent. The absorption of capital expenditure at the end of the third quarter indicates that 43.90 percent SKPD managing capital expenditures tend to experience delays in budget absorption. That is, 56.10 percent do not fall into the category of late because the absorption rate of the budget is above 68 percent.

Budget planning and budget execution is factors that influence the absorption of the budget significantly while the capacity of human resources has no significant effect. Budget absorption has a positive and significant effect on the performance of Jambi Provincial Government institution.

\section{Recommendations}

Giving reward/punishment for SKPD that succeeded/failed in implementing financial management so that the management of regional finance in the future becomes more effective, efficient and timely in budget absorption so that the resulting outcome can be useful and enjoyed by the community.

The acceleration and optimization of budget absorption can be done through good budget planning and budget execution conducted appropriately and in accordance with schedule so that the implementation of programs and activities can reach the target in order to improve the performance of the institution.

The development of further research to expand the budget absorption analysis, by adding other factors that may be taken into consideration in the absorption of the budget such as external SKPD environment factors, budgetary supervision, time of budgeting, the remainder of the previous year's budget.

\section{BIBLIOGRAPHY}

Aini, R.Noor. (2016). Analisis Kecenderungan Penumpukan Penyerapan Anggaran Belanja (Studi Kasus pada Pemerintahan Kabupaten Bantul). Tesis. Program Studi Magister Akuntansi. Universitas Gajah Mada : Yogyakarta. 
Fitriany, N., GN. Masdjojo, \& T. Suwarti. (2015). Exploring The Factors that Impact The Accumulation of Budget Absorption in The End of The Fiscal Year 2013 : A Case Study in Pekalongan City of Central Java Indonesia. South East Asia Journal of Contemporary Business, Economics and Law. Vol.7, Issue 3 (Aug) ISSN 2289-1560.

Halim, Abdul. (2016). Manajemen Keuangan Sektor Publik. Edisi Kedua. Penerbit Salemba Empat : Jakarta.

Haspiarti. (2012). Pengaruh Penerapan Anggaran Berbasis Kinerja terhadap Akuntabilitas Kinerja Instansi Pemerintah Kota Pare-Pare. Universitas Hasanuddin : Makasar.

Herriyanto, Hendris. (2012). Faktor-faktor yang Mempengaruhi Keterlambatan Penyerapan Anggaran Belanja pada Satuan Kerja Kementerian/Lembaga di Wilayah Jakarta. Tesis. FE Universitas Indonesia : Jakarta.

Kuswoyo, I. Dwi. (2012). Analisis Faktor-faktor yang Menyebabkan Terkonsentrasinya Penyerapan Belanja di Akhir Tahun Anggaran pada Satuan Kerja di Wilayah KPPN Kediri. Tesis-Abstrak. Pasca Sarjana Universitas Gajah Mada : Yogyakarta.

Malahayati, C., Islahuddin, \& H.Basri. (2015). Pengaruh Kapasitas Sumber Daya Manusia, Perencanaan Anggaran dan Pelaksanaan Anggaran terhadap Serapan Anggaran Satuan Kerja Perangkat Daerah (SKPD) pada Pemerintah Kota Banda Aceh. Jurnal Magister Akuntansi. Vo.4, No.1, pp.11-19, Februari 2015. Pasca Sarjana Universitas Syiah Kuala : Banda Aceh.

Mardiasmo. (2009). Akuntansi Sektor Publik. Penerbit ANDI : Yogyakarta.

Maulana, Delly. (2011). Analisis Penelusuran Anggaran APBD Provinsi Banten di Sektor Pembangunan Sumber Daya Manusia. Simposium Nasional Otonomi Daerah 2011. Universitas Serang Raya : Banten.

Miliasih, Retno. (2012). Analisis Keterlambatan Penyerapan Anggaran Belanja Satuan Kerja Kementerian/Lembaga TA 2010 di Wilayah Pembayaran KPPN Pekanbaru. Tesis. Universitas Indonesia : Jakarta.

Ministry of Finance, Planning and Economic Development of Uganda. (2011). Absorptive Capacity Constraints: The Causes and Implications for Budget Execution Uganda. East Africa : Development Policy and Research Department.

Muchsin, M. \& A.S. Noor. (2011). Fenomena Penyerapan Anggaran : Kenapa Akselerasi di Akhir Tahun?. Paris Review BPKP : Yogyakarta.

Rifai, A., BA. Inapty, \& Rr. S. Pancawati M. (2016). Analisis Faktor-faktor yang Mempengaruhi Keterlambatan Daya Serap Anggaran (Studi Empiris pada SKPD Pemprov NTB). Jurnal Ilmiah Akuntansi dan Bisnis. Vol.11, No.1 Januari 2016. FEB Universitas Mataram : NTB.,

Rozai, M.Ali \& L.Subagiyo. (2015). Optimalisasi Penyerapan Anggaran dalam Rangka Pencapaian Kinerja Organisasi. Jurnal Manajemen Sumber Daya Manusia , Vol.9 No.1, 72-89.

Ruwaida, Darwanis, \& S. Abdullah. (2015). Faktor-faktor yang Mempengaruhi Realisasi Anggaran Belanja Pendidikan di Provinsi Aceh. Jurnal Magister Akuntansi. Vol.4, No.4, November 2015. Pasca Sarjana Universitas Syiah Kuala : Banda Aceh.

Septianova, R. \& H. Adam. (2013). Pengaruh Kualitas DPA dan Perencanaan Kas terhadap Kuaalitas Penyerapan Anggaran pada Satker Wilayah KPPN Malang. JRAK. Vol.4. No.1, Hal.75-84. 
Siswanto D.A \& Rahayu L.S. (2011). Faktor-faktor Penyebab Rendahnya Penyerapan Belanja Kementrian/ Lembaga. http:/www.kemenkeu.go.id/sites/default/files/ artikel_dan_opini/Kementerian_lembaga .pdf. di akses pada 15 September 2016.

Stepanus. (2014). Pengaruh Budaya Organisasi, Gaya Kepemimpinan, dan Motivasi Kerja terhadap Kinerja Pegawai. Jurnal Studia Akuntansi dan Bisnis Vol. 1 No. 2, (2013-2014).

Yunarto, Imam. (2011). Memahami Proses Penganggaran untuk Mendorong Optimalisasi Penyerapan Anggaran. Paris Review BPKP : Yogyakarta.

Zarinah, Monik. (2015). Pengaruh Kualitas Sumber Daya Manusia dan Perencanaan Anggaran terhadap Tingkat Penyerapan Anggaran Satuan Kerja Perangkat Daerah di Kabupaten Aceh Utara. Tesis. Pasca Sarjana Universitas Syiah Kuala : Banda Aceh.

Zarinah, M., Darwanis, \& S. Abdullah. (2016). Pengaruh Kualitas Sumber Daya Manusia dan Perencanaan Anggaran terhadap Tingkat Penyerapan Anggaran Satuan Kerja Perangkat Daerah di Kabupaten Aceh Utara. Jurnal Magister Akuntansi. Vol. 5, No.1, pp.11-19, Februari 2016. Pasca Sarjana Universitas Syiah Kuala : Banda Aceh.

Peraturan Pemerintah Republik Indonesia Nomor 58 Tahun 2005 tentang Pengelolaan Keuangan Daerah 